\title{
Investment Banks and Credit Institutions: The Ignored and Unregulated Diversity
}

\section{Fabrizio Pezzani*}

Department of Policy Analysis and Public Management, Bocconi University, Milan, Italy

\section{Keywords: Banks; Credit; Unregulated diversity; Finance}

\section{Short Communication}

The problems that have swept the world of finance and credit in recent years, the bankruptcy of some national italian banks and the ensuing social dramas, are seen and discussed with staggering shortsightedness and an incapacity to understand the real causes that have led us to becoming hostages of a collapsed socio-cultural model. The real roots of this cultural, social and financial disaster can be attributed to the role that finance - with its epicentre in Wall Street - has taken on over time, becoming subordinate to the real economy and entirely deregulated. The wind of finance on the real economy has been fanned by decades of deregulation after 1971 the end of "gold-exchange standard" to "dollar - exchange - standard" and development of infinite monetary system as in this graphic (Figure 1).

After, the deregulation has been legalized by the Nobel prizes of the nineties (Markowitz-innovative finance, Lucas - rational markets, Merton and Scholes-rational derivatives) and finally by the Fed that in 1999 contributed to breaking down the wall that Roosevelt struggled to erect to divide the fields of activity of investment banks from traditional lenders [1].

Alan Greenspan in that year supported the abolition of the GlassSteagall Act instigated by the Italian-American Ferdinand Pecora - Chief Counsel to the United States Senate Committee on Banking - and adopted by the Roosevelt administration in 1933 to curb the financial speculation that engendered the Great Depression. The act had two essential aims to stabilize the financial markets and in theory strengthen the role of the Fed as controller in its intended institutional function. The first aim of the act was the establishment of the Federal Deposit Insurance Corporation to guarantee deposits and prevent possible bank runs in the event of investors panicking. The second was to separate the functional activities of investment banks and traditional lenders to prevent that the same agency performed the two activities simultaneously and thus avoid exposing the real economy to pure financial speculation [2]. The deeds that led to the Great Depression were related to excess speculation, placing finance over the real economy and eroding savings, just as is occurring today. Roosevelt, with the cooperation of Keynes, had started a virtuous cycle that would serve to reconstruct the fragmented social system and prepare for the great post-war development founded on the real economy and shut down speculation as an end in itself.

The repeal of the Glass-Steagall Act that separated the scope of activities of the two different categories of banks took place in 1999 and was replaced by the Gramm-Billey Act, recreating the conditions that had led to the Great Depression, igniting the financial storm with subprime lending, derivatives and all the arsenal of toxic and amoral finance [3].

Greenspan deregulated derivatives and other toxic products such as subprime lending because he considered them a positive financial innovation for the functioning of the free market, 'beneficial' for consumers (!) and without consequences. In fact, increasing deregulation - he said - would be tempered by the rationality (nonexistent) of markets, as regularly seen. To emphasise the absolute truth, Ben Bernanke before the US Congress Joint Economic Committee in 2007 - a year before the collapse - observed, "At this juncture, however, the impact on the broader economy and financial markets of the problems in the subprime market seems likely to be contained". That same year, Treasury Secretary Henry Paulson dismissed the threat of the subprime market stating, "I don't think it poses any threat to the overall economy": extraordinary prophets of nothingness. Bernanke, only a year after he had offloaded onto the shoulders of Americans the insignificant sum of 11,000 billion/\$ to save the banks from subprime lending (for the record, in 2013, the US Justice Department sentenced the investment banks for fraudulent manipulation of asset values that resulted in the crisis). When an official body such as the Fed legitimates speculative activity as an end in itself, market expectations of infinite and illusory growth ensue and at that point, the derivatives market explodes, as shown in these graphs (Figure 2).

The road to finance and investment bank employment had already been paved in 1971 when the US unilaterally declared the end of the dollar's convertibility into gold, \$28 per gram of gold. The currency was unhooked from the real economy, able to assume an uncontrolled and therefore infinite volume [4]. From there the path was short and devastating because finance came to dominate the real economy by giving everyone the impression of being in the sphere of miracles, in exactly the same way as when the cat and fox tell Pinocchio to plant his coins and grow a tree bearing gold.

The goal of profit maximization justified both deregulation and unbridled liberalism where the strongest - not the best - win and the others lose. Liberalism without rules constructed as the ends has led to the end of all controls, justifying the normalization of illicit behaviour. The collapse of Lehman Brothers in 2008 was just the tip of the iceberg as we have and are seeing; the controllers are now colluding with the controlled and everything has fallen apart. "Quis custodiet ipsos custodes? [But who watches the watchmen?]" wrote Juvenal in his Satire and that is precisely the case today because human nature has never changed. This finance model allowed investment banks to resume a speculative role, fuelled by the "create shareholder value" mantra that until 1999 had been mitigated by the Glass-Steagall Act. Financial neoliberalism then separated capital from work, delocalizing it to chase infinite wealth with countries placing themselves in a supranational dimension [5].

*Corresponding author: Fabrizio Pezzani, Department of Policy Analysis and Public Management, Bocconi University, Milan, Italy, Tel: 39 025836.3045; E-mail: fabrizio.pezzani@unibocconi.it

Received June 13, 2016; Accepted July 06, 2016; Published July 16, 2016

Citation: Pezzani F (2016) Investment Banks and Credit Institutions: The Ignored and Unregulated Diversity. Bus Eco J 7: 224. doi:10.4172/2151-6219.1000224

Copyright: $(2016$ Pezzani F. This is an open-access article distributed under the terms of the Creative Commons Attribution License, which permits unrestricted use, distribution, and reproduction in any medium, provided the original author and source are credited. 
Citation: Pezzani F (2016) Investment Banks and Credit Institutions: The Ignored and Unregulated Diversity. Bus Eco J 7: 224. doi:10.4172/21516219.1000224

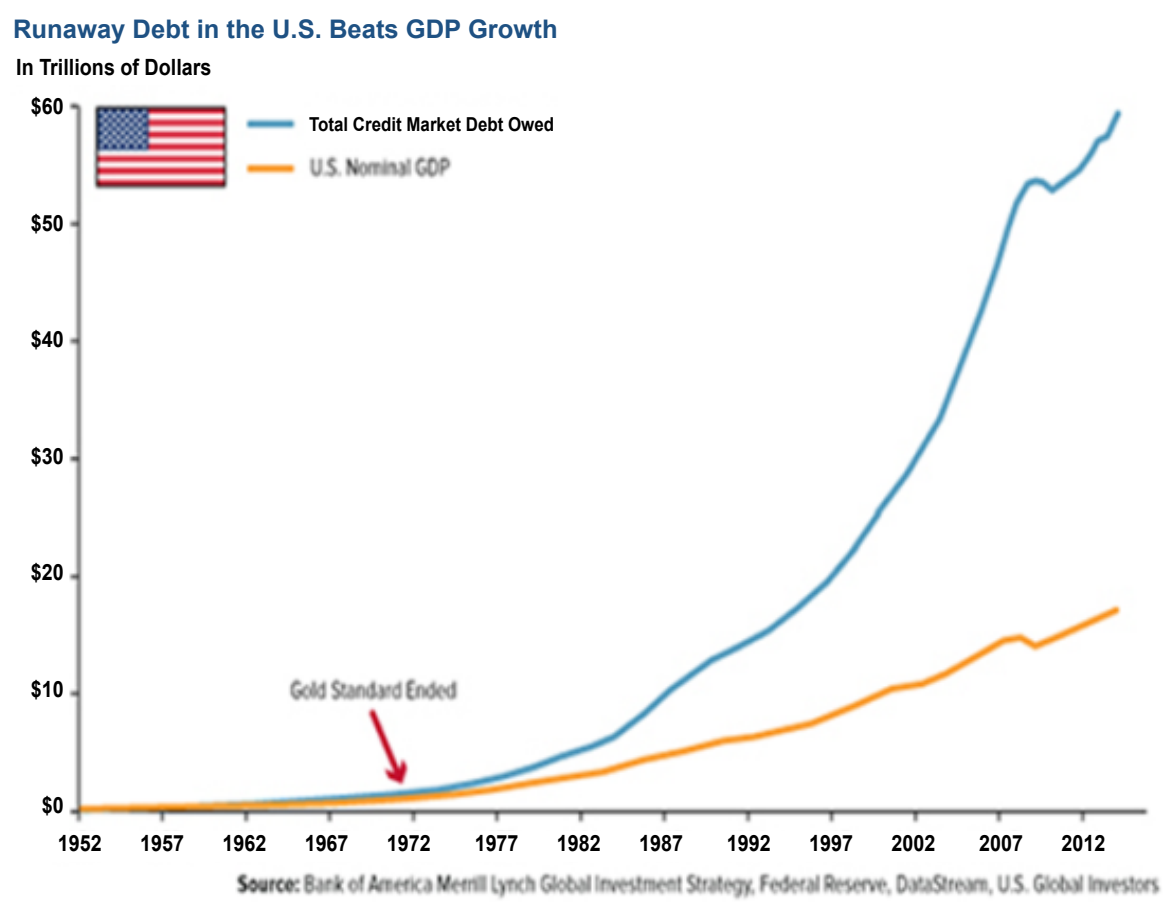

Figure 1: Runway Debt in the U.S. Beats GDP Growth.

Derivative Market Vs. World GDP

800Trillion

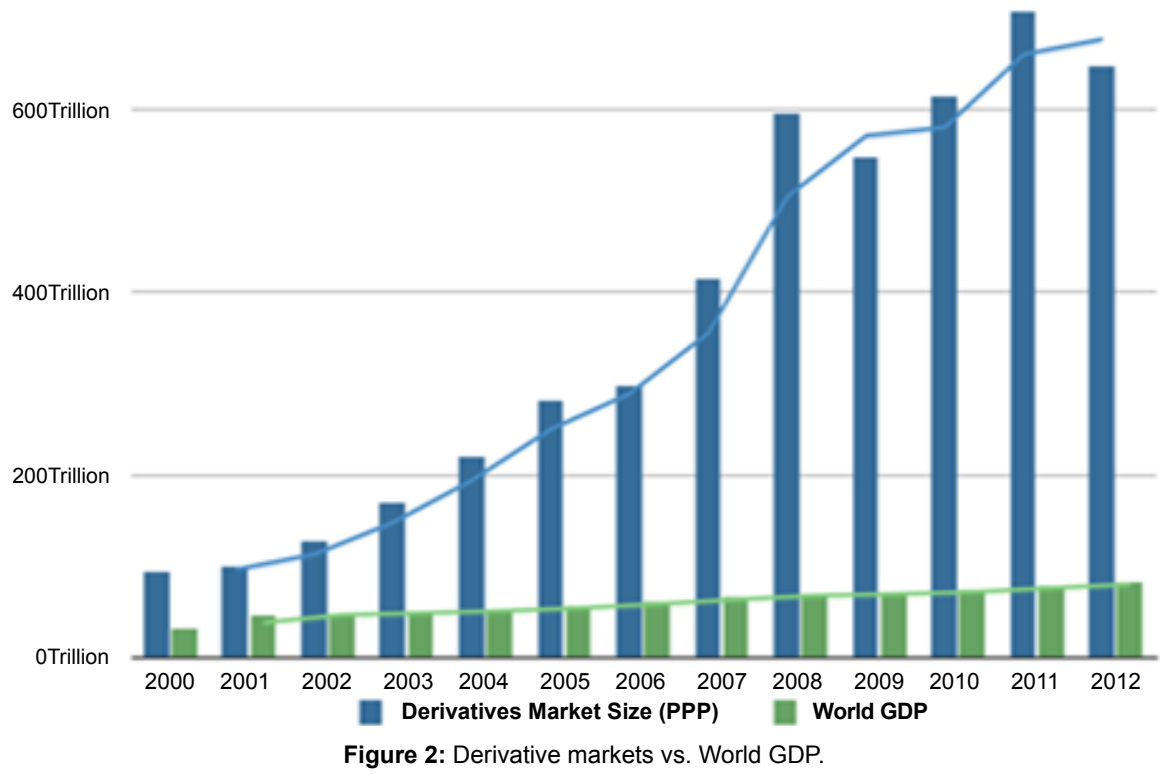

Financial markets have been transformed into a casino by speculation that continuously buys and sells. High-frequency trading has become an electronic commerce based on mathematical models that make the decisions in an infinite world where the speculations never meet with the finite reality but always end up distorting it to guide and manipulate markets and create the conditions of financial weakness with progressive global debt to keep the political and global decisions in check [5]. "When the capital development of a country becomes a by-product of the activities of a casino, the job is likely to be ill-done" recalled Keynes in 1931, but the greed of man always has a short memory.

Investment banking and the market culture undermined the American system and then much like a tsunami invaded other countries starting from the old Europe whose culture was opposed because it is linked to the welfare system and not to that of the market as the 
Citation: Pezzani F (2016) Investment Banks and Credit Institutions: The Ignored and Unregulated Diversity. Bus Eco J 7: 224. doi:10.4172/21516219.1000224

Page 3 of 4

US. The Brussels bureaucrats did not, or did not want to, understand the tsunami wave that was coming and passively suffered a cultural colonization that went against history, erasing it in one fell swoop. The wave then hit Italy where the ancient culture of saving, "putting hay in the barn", the real economy and the retail banks had held until then. The dominant culture has become absolute truth not to be questioned, to foolishly imitate and the 1993 State derivates are the obvious example. This culture, uncritically assumed, started causing damage from the oldest bank in the country (MPS - Monte Paschi Siena) that in five years of derivatives emptied its harvest of savings made in the previous 450 years. The line eroded that separated investment banks from traditional lending institutions in a country that did not have the culture and the skills to do so; we magically transformed from extraordinary and winning artisans to losing financiers without culture and expertise in selling products governed by others. No one has had the courage to attempt a little self-criticism and the media have ended up bundling everything together into the term bank: those who have kept to the old road continuously innovating and consolidating with deeds, and those that have and are getting results with finance rather than the real economy. Today, in their freedom of choice and for their protection, citizens need regulatory control and clarification of the difference between institutions in charge of credit and the real economy linked to the territory in a long-term and capital preservation approach, and those institutions more inclined to viewing finance in a short or very short-term logic within a global system but with higher risks. The specific activities and products of the different types of banks need to be strictly defined as well as the related responsibilities, enforcing them without continuing to blame each other and harming themselves (Figures 3 and 4).

"Humanum fuit errare, diabolicum est per animositatem in errore manere" Saint Augustine wrote in his Sermons $(164,14)$. To err is human, but to remain in error out of stubbornness, is diabolical.

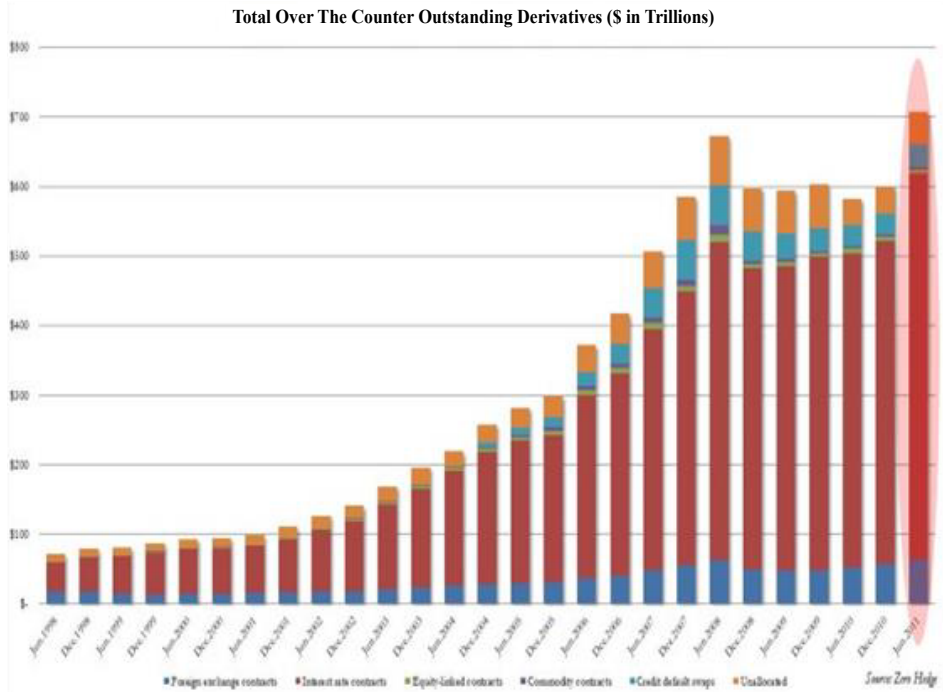

Figure 3: Total over the counter outstanding derivatives.

Ratio of Total WEO to outstanding derivatives

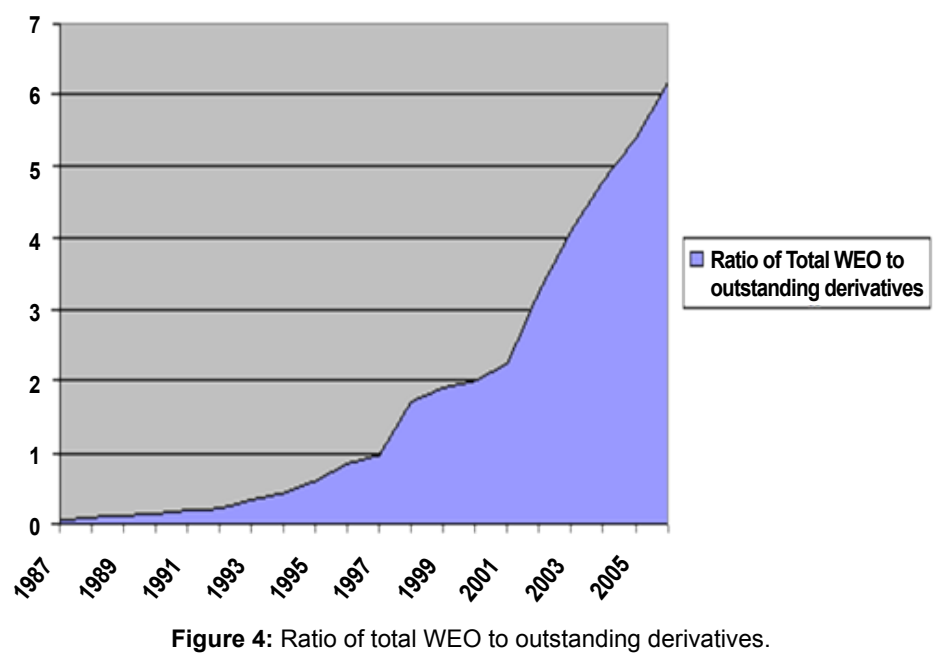


Citation: Pezzani F (2016) Investment Banks and Credit Institutions: The Ignored and Unregulated Diversity. Bus Eco J 7: 224. doi:10.4172/21516219.1000224

Page 4 of 4

\section{References}

1. Woodard (2013) The Market for Derivatives is Not Bigger Than World GDP. The Street.

2. ISDA (2012) OTC Derivatives Market Analysis Year-end 2011. International Swaps and Derivatives Association, Inc. 1-12.
3. Bank for International Settlements (2015) OTC derivatives statistics at end June 2015. Monetary and Economic Department.

4. Quiscus (2013) Quis Custodietlpsos Custodes?

5. Keynes JM (1931) Activities 1931-1939 World Crises and Policies In Britain And America. Macmillan Cambridge University Press, Royal Economic Society. 